\author{
А. Ф. Рубцов
}

Біосферний заповідник «Асканія-Нова» ім. Ф. Е. Фальи-Фейна УААН

\title{
ДЕЯКІ АСПЕКТИ ВДОСКОНАЛЕННЯ \\ ПРИСКОРЕНОГО РОЗМНОЖЕННЯ МАЛОПОШИРЕНИХ ЕКЗОТІВ \\ ТА ВИСОКОДЕКОРАТИВНИХ КУЛЬТИВАРІВ У ПІВДЕННО-СТЕПОВОМУ РЕГІОНІ УКРАЇНИ
}

Розроблено та апробовано технології агротехніки генеративного прискореного розмноження листопадного малопоширеного екзота Liriodendron tulipifera L., прискореного вегетативного розмноження 16 видів листопадних і 8 таксонів малопоширених екзотів та високодекоративних культиварів (строки заготівлі та посадки живців, укорінення тощо).

$$
\text { A. F. Rubtsov }
$$

F. E. Falz-Fein Biosphere Reserve «Askania-Nova» of UAAS

\section{SOME ASPECTS FOR IMPROVEMENT \\ OF ACCELERATED REPRODUCTION OF NOT WIDESPREAD EXOTICS AND HIGHLY ORNAMENTAL CULTIVARS IN THE SOUTHERN STEPPE REGION OF UKRAINE}

The technologies of agrotechnics of accelerated generative reproduction of the not widespread therophyllous exotic Liriodendron tulipifera $L$., accelerated vegetative reproduction of 16 therophyllous species and 8 taxa of evergreen exotics and highly ornamental cultivars (the terms of grafts storage and planting, rootage, etc.) are worked up and approved.

\section{Вступ}

Останнім часом у нашій державі, як і в усьому світі, посилився інтерес до використання у практиці озеленення малопоширених екзотів (ME) і стійких високодекоративних культиварів (ВК). Саме $з$ допомогою рослин цих унікальних категорій створювались і створюються шедеври садово-паркового мистецтва, а потреба у них всебічно зростає. Український ринок декоративного мистецтва (та південно-степового регіону зокрема) зазнає значного дефіциту посадкового матеріалу $\mathrm{ME} \mathrm{i} \mathrm{BК,} \mathrm{який} \mathrm{покривається}$ за рахунок увезення 3-за кордону. Але привозні рослини занадто дорогі, нестійкі та не адаптовані до наших екологічних умов. Тому розробки в цьому напрямку мають певні перспективи, але їх практичне використання бажає кращого. У провідних регіональних репродуктивних центрах країни (Київ, Донецьк, Харків, Львів, Ялта) при розмноженні ME і ВК перевагу віддають живцюванню. Генеративне розмноження залишається в межах експерименту.

У південностеповому аридному регіоні питання прискореного розмноження деревних екзотів практично не вирішується. Це пов'язано з гострим впливом кризового стану економіки на сферу зеленого будівництва. Повсюдно зменшуются масштаби робіт з озеленення та паркобудівництва, скорочуються площі зелених насаджень усіх ка- 
тегорій користування. Парки малих міст і сіл покинуті напризволяще. Немало периферійних промислових розсадників припинили існування, а функціонуючі - ледь-ледь животіють і значно скоротили свій асортимент. Причин тому безліч, але основна - недостатнє фінансування розсадників і нерозвинена інвестиційна система їх діяльності. Суттєвим негативним явищем у цьому є недостатня розробка питань прискореного розмноження деревних високодекоративних екзотів у регіональному плані, слабка їх маточна та насіннєва база. Тому розробки з вегетативного та генеративного прискореного розмноження тут досить актуальні й заслуговують на значну увагу.

\section{Матеріал і методи досліджень}

Рекомендації провідних спеціалістів - Л. Ф. Правдіна (1938), Б. С. Срмакова (1975), 3. Я. Іванової (1987) та інших, а також наш попередній досвід роботи у цьому напрямку дали нам змогу обрати основні технології прискореного розмноження МЕ та ВК і провести цикл експериментальних робіт у 2001-2005 роках.

Із генеративного розмноження розроблена та успішно апробована технологія розмноження ME північно-американського походження Liriodendron tulipifera L. (ліріодендрон тюльпанний) способом посіву насіння (Некрасов, 1973).

Із вегетативного живцювання здерев'янілими (зимовими) та напівздерев'янілими (літніми, зеленими) живцями в поглиблених холодних парниках розмножено 16 видів листопадних та 8 вічнозелених деревних рослин із різним ступенем ризогенезу (високим, середнім, слабким). Здерев'янілі живці листопадних МЕ та ВК заготовляли та висаджували в II-III декаді березня - I декаді квітня (період від фази набухання бруньок до початку їх розпускання). Зимові живці вічнозелених - у період найактивнішої камбіальної діяльності (III декади березня - I декади квітня до II декади травня). Літні, напівздерев'янілі (зелені) живці листопадних - відповідно, у період із III декади квітня I декади травня до II декади червня (відразу після закінчення фази цвітіння). Живці (літні) вічнозелених - у II декаді квітня - I декаді травня до I-III декад червня.

\section{Результати та їх обговорення}

У плані генеративного розмноження ME Liriodendron tylipifera за вегетативний сезон одержані нормально розвинуті сіянці до 20 см висоти з виходом $35-45 \%$ від посіяного насіння. За основну технологію прийнято пізньоосінній рядковий посів у відкритий грунт свіжозібраним насінням без стратифікації на глибину до 5 см із засипанням спеціальною сумішшю (пісок, перегній, листяна земля та тирса). Відстань між рядками 25-30 см; норма висіву - до 100 шт. на 1 п/м. Притінення обов'язкове, як і регулярний полив сходів через 7-10 діб після посіву. Менш ефективний ранньовесняний посів, агротехніка якого ідентична, за винятком того, що посів здійснюється стратифікованим насінням.

При розробці агротехніки вегетативного розмноження за основну технологію взято живцювання стебловими здерев'янілими та напівздерев'янілими живцями у поглиблених холодних парниках із плівковим покриттям, заповнених чистим крупнозернистим річковим піском, регульованим вручну дрібнодисперсним зволоженням, із подальшим дорощуванням укорінених рослин у відкритому грунті, а також у плівкових контейнерах (табл.).

Слід зазначити, що листопадні рослини з високим і середнім ступенем ризогенезу можна розмножувати як здерев'янілими (зимовими), так і зеленими (літніми) живцями. Але укорінення здерев'янілими живцями менш енергомістке та більш економічне. Йому слід віддавати перевагу. При вегетативному розмноженні деревних рослин із 
низьким ступенем ризогенезу (III група) одержано негативні результати. Судячи з них, живцювання літніми (зеленими) живцями взагалі економічно невигідне при використаній технології, і для цих рослин потрібні подальші розробки та вдосконалення як агротехнічних прийомів (термін заготівлі живців, обробка стимуляторами росту тощо), так і умов зволоження (туманоутворення з автоматичним регулюванням).

Таблиия

Укорінення стеблових живців листопадних і вічнозелених рослин у 2001-2005 рр. (середньорічні показники)

\begin{tabular}{|c|c|c|c|c|c|c|}
\hline \multirow{3}{*}{ Група } & \multirow{3}{*}{$\begin{array}{c}\text { Період } \\
\text { вегетації }\end{array}$} & \multirow{3}{*}{$\begin{array}{c}\text { Назва рослин } \\
\text { (вид, форма, сорт) }\end{array}$} & \multicolumn{4}{|c|}{ Укорінення живців } \\
\hline & & & \multicolumn{2}{|c|}{$\begin{array}{l}\text { здерев’янілі } \\
\text { (зимові) }\end{array}$} & \multicolumn{2}{|l|}{$\begin{array}{r}\text { зелені } \\
\text { (літні) }\end{array}$} \\
\hline & & & $\begin{array}{c}\text { тривалість, } \\
\text { діб }\end{array}$ & $\%$ & $\begin{array}{c}\text { тривалість, } \\
\text { діб }\end{array}$ & $\%$ \\
\hline \multirow{8}{*}{$\begin{array}{c}\text { I група - } \\
\text { рослини } \\
\text { з високою } \\
\text { регенера- } \\
\text { тивною } \\
\text { здатністю }\end{array}$} & \multirow{6}{*}{$\begin{array}{l}\text { листо- } \\
\text { падні }\end{array}$} & Forsythia suspensa (Thunb.) Vahl. & 35 & 89,0 & 28 & 73 \\
\hline & & Deutzia scabra Thunb. 'Plena' & 29 & 73,0 & 21 & 61,0 \\
\hline & & Kerria japonica L. 'Plena' & 32 & 58,0 & 23 & 60,0 \\
\hline & & Lonicera brownii (Regel) Carr. & 37 & 61,0 & 30 & 31,0 \\
\hline & & Viburnum opulus L. & 51 & 64,0 & 43 & 57,0 \\
\hline & & Viburnum opulus L. 'Roseum' & 49 & 53,0 & 41 & 61,0 \\
\hline & \multirow{2}{*}{$\begin{array}{l}\text { вічно- } \\
\text { зелені }\end{array}$} & Buxus sempervirens L. & 62 & 95,0 & 53 & 69,0 \\
\hline & & Taxus baccata $\mathrm{L}$ & 68 & 79,0 & 76 & 23,0 \\
\hline \multirow{9}{*}{$\begin{array}{c}\text { II група - } \\
\text { рослини із } \\
\text { середньою } \\
\text { регенера- } \\
\text { тивною } \\
\text { здатністю }\end{array}$} & \multirow{6}{*}{$\begin{array}{l}\text { листо- } \\
\text { падні }\end{array}$} & Rosa hybrida hort. 'Gloria Dei' & 58 & 72,0 & 32 & 87,0 \\
\hline & & Syringa josikaea Jacq. & 67 & 56,0 & 49 & 71,0 \\
\hline & & Syringa vulgaris L. & 59 & 51,0 & 48 & 65,0 \\
\hline & & Philadelphus coronarius L. & 46 & 49,0 & 38 & 47,0 \\
\hline & & Platanus acerifolia Willd. & 85 & 37,0 & 72 & 51,0 \\
\hline & & Juniperus sabina L. & 53 & 63,0 & 90 & 18,0 \\
\hline & \multirow{3}{*}{$\begin{array}{l}\text { вічно- } \\
\text { зелені }\end{array}$} & Chamaecyparis pisifera Sieb. et Zucc. & 67 & 50,0 & 112 & 11,0 \\
\hline & & Platycladus orientalis (L.) Franco 'Aurea' & 63 & 71,0 & 88 & 17,0 \\
\hline & & Thuja occidentalis L. 'Fastigiata' & 52 & 49,0 & 93 & 21,0 \\
\hline \multirow{7}{*}{$\begin{array}{c}\text { III група - } \\
\text { рослини } 3 \\
\text { низькою } \\
\text { регенера- } \\
\text { тивною } \\
\text { здатністю }\end{array}$} & \multirow{5}{*}{$\begin{array}{l}\text { листо- } \\
\text { падні }\end{array}$} & Corylus avellana L. 'Atropurpurea' & - & - & 70 & 3,0 \\
\hline & & Crataegus monogyna Jacq. 'Roseo-plena' & - & - & - & - \\
\hline & & Ginkgo biloba $\mathrm{L}$. & 88 & 5,0 & - & - \\
\hline & & Liriodendron tulipifera $\mathrm{L}$. & - & - & - & - \\
\hline & & Louiseania triloba (Lindl.) Pochom. & - & - & - & - \\
\hline & \multirow{2}{*}{$\begin{array}{l}\text { вічно- } \\
\text { зелені }\end{array}$} & Abies concolor (Gord.) Hildebr. & - & - & - & - \\
\hline & & Picea glauca (Moench) Voss. 'Conica' & 152 & 5,0 & - & - \\
\hline
\end{tabular}

Укорінення стебловими зеленими живцями вічнозелених рослин (за винятком самшиту вічнозеленого) у холодних парниках за прийнятою технологією взагалі не має практичного сенсу, тоді як при використанні зимових живців майже в усіх вічнозелених видів дає непоганий результат, окрім порід із низькою регенераційною здатністю.

Також проведено пошукові експерименти з удосконалення способу зволоження у період калюсоутворення. Перевірялись два варіанти на рослинах трьох порід: Deutzia scabra, Juniperus sabina, Philadelphus coronarius: вплив на укорінення в умовах «вологої камери» (поліетиленовий ковпак); вплив на укорінення обгортання нижньої частини живця фільтрувальним папером.

Одержано позитивні дані щодо калюсоутворення та укорінення живців із використанням «вологої камери», де процеси регенерації кореневої системи проходять швидше, ніж у холодних парниках. У другому варіанті (обгортання нижньої частини живця фільтрувальним папером) результати калюсоутворення на 5-7 \% нижчі контролю та на 11-16 \% нижчі I варіанта. Масове калюсоутворення настає на 8-10 діб пізніше 
контролю і на 11-13 діб пізніше, ніж із використанням «вологої камери». Очевидно, обгортання фільтрувальним папером інтенсифікує процеси загнивання живців. Але цей експеримент має пошуковий характер і його необхідно перевірити в майбутньому. Перспективним, на нашу думку, може бути варіант із насиченням фільтрувального паперу дезинфікуючим розчином.

\section{Висновки}

Основним способом прискореного генеративного розмноження малопоширеного екзота Liriodendron tulipifera L. на півдні степової зони України $є$ пізньоосінній рядковий посів свіжозібраного насіння без стратифікації в грядці на глибину до 5 см із засипанням спеціальною сумішшю. Міжрядкова відстань - 25-30 см; норма висіву - до 100 шт./п.м. Притінення та регулярний полив обов'язкові.

Прискорене вегетативне розмноження тут МЕ та ВК рекомендується живцюванням у поглиблених холодних парниках із плівковим покриттям і регульованим (вручну) дрібнодисперсним зволоженням. Найефективніше, менш енергомістке і більш економічне укорінення зимовими здерев'янілими живцями. Оптимальні строки посадки та заготівлі живців - весна (період активності камбіальної діяльності пагонів).

\section{Бібліографічні посилання}

1. Ермаков Б. С. Выращивание сеянцев методом черенкования - М.: Лесная пром-сть, 1975. $152 \mathrm{c}$.

2. Иванова 3. Я. Биологические основы и приемы вегетативного размножения древесных растений стебельными черенками. - К.: Наукова думка, 1982. - 288 с.

3. Некрасов В. И. Основы семеноведения древесных растений при интродукции. - М.: Наука, 1973. $-280 \mathrm{c}$.

4. Правдин Л. Ф. Вегетативное размножение растений. - Л.: Сельхозгиз, 1938. - 292 с.

Надійшла до редколегії 15.05.2008 